Copyright (C) 2015 by Academic Publishing House Researcher

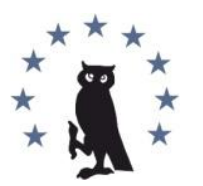

Published in the Russian Federation

European Researcher

Has been issued since 2010.

ISSN 2219-8229

E-ISSN 2224-0136

Vol. 98, Is. 9, pp. 684-690, 2015

DOI: 10.13187/er.2015.99.684

www.erjournal.ru

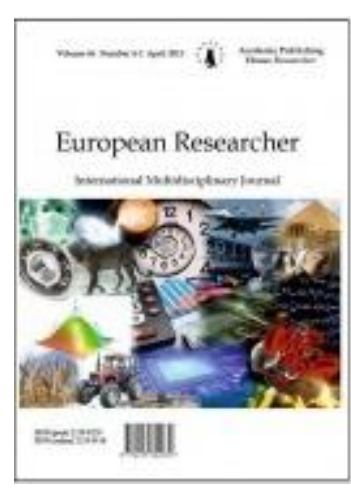

Pedagogical sciences

Педагогические науки

UDC 37

\title{
Ethical Analysis of the Functioning of Media in Society and Media Texts in the Classroom
}

\begin{abstract}
Alexander Fedorov
Anton Chekhov Taganrog Institute, Russian Federation

branch of Rostov State University of Economics

Prof. Dr. (Pedagogy)

E-mail: mediashkola@rambler.ru

\section{Abstract}

Ethical analysis of the functioning of media in society and media texts based on the ethical theory of media. It is assumed that the media are able to form certain audience's moral principles. From this follows the main goal of media literacy ethics education: to involve the audience in a particular ethical behaviors (corresponding, for example, a particular religion, level of civilization, democracy, etc.). Teaching strategy is based on the study of ethical aspects of media and ethical analysis of media texts.

This article presented the main directions for Ethical Analysis on media literacy education classes for student audience, including the examples of creative problems and issues associated with this type of the analysis in the context of media literacy education problems, ie based on six key concepts of media literacy education: agency, category, language, technology, audience, representation. The author supposes that the Ethical Analysis of media texts on media literacy education classes can significantly develop media competence of students, including critical thinking and perception.
\end{abstract}

Keywords: ethical analysis, media, media texts, media education, media literacy, media competence, students.

\section{Introduction}

Ethical analysis of the functioning of media in society and media texts based on the ethical theory of media. It is assumed that the media are able to form certain audience's moral principles. From this follows the main goal of media literacy ethics education: to involve the audience in a particular ethical behaviors (corresponding, for example, a particular religion, level of civilization, democracy, etc.). Teaching strategy is based on the study of ethical aspects of media and ethical analysis of media texts [Penzin, 1987, p.47; Malobitskaya, 1979, p.16]. It is clear that the moral 
values in this case essentially depend on the socio-cultural and political context. For example, during the totalitarian regime in Russia, it was believed that students "with proper preparation for watching movies and as a result will blame lies, evil deeds and, conversely, students will have a positive attitude towards everything that meets the requirements of high communist morality" [Uritzky, 1954, p.42]. Their claims to the ethical theory of media education, no doubt, are presented, for example, Muslim or Buddhist countries, which proves the close relationship of ethical and religious theories of media education.

\section{Materials and methods}

The main material for this article was the area of the books and articles about the ethical analysis of the functioning of media in society and media texts. Ethical analysis of media and media texts implies a number of students of creative tasks [BFI, 1990, 2003; Buckingham, 2003; Semali, 2000, pp.229-231; Potter, 2001, p.34; 2014; Berger, 2005; Nechay, 1989, pp. 267-268; Fedorov, 2004, pp.43-51; Silberblatt, 2001; 2014]: literary simulation, role game, fine-simulation. Each of these tasks include analysis of the key concepts of media literacy education (media agencies, media categories, media language, media technologies, media representations, media audiences, etc.).

\section{Discussion}

For the advent of the postmodern era - with its characteristic as an ironic attitude to life in general and to any works of culture / art - a phrase that "modern teacher - the defender of moral and aesthetic values" [Odintsova, 1993, p.113], began to be perceived as annoying archaic. It seemed that the theory of media education as "media consumption" needs of the audience spontaneously formed looks the most "advanced" and up to date. Meanwhile, at the beginning of the XXI century for many educators and researchers became apparent that "at the juvenile environment continues to grow pragmatism, alienation from cultural ideals of morality, beauty and creativity. Dehumanization of consciousness, the devaluation of moral and aesthetic values, lack of spirituality became characteristic features of youth" [Khilko 2001, p.5].

Media cynics and "nihilists" can (with a sarcastic grin) show any filth of life, justifying it needed unlimited freedom of expression. It is well known also that in case of technically "media literacy" villains use of media as an aid to terrorist acts, taking of hostages and harried face victims of violence, real torture, murder, etc.

That is why the ethical theory of media education, based on democratic values, humanism, ethnic, national, racial and religious tolerance seems very relevant today. For example, M. Beron and L. Rother point out that the current political, social and ideological climate in some countries leads to a return to this kind of ethical and protectionist pedagogy, as students should be protected from evil, immoral, unethical influence of the media, "vaccinated" against the "virus" artificially created commercially interested media structure image of the consumer [Baron, Rother, 2003].

\section{Results}

Literary creative tasks that promote ethical reflection about the functioning of the media in society and media texts:

Media agencies:

- creation of the stories on behalf of different ethical positions of media agency regarding the various ethical problems.

Media / media text categories:

- writing of monologues for typical characters of comedy, tragedy, melodrama, detective, western, etc., that address ethical issues.

\section{Media languages:}

- writing of dialogue between the two artists (directors, cameramen, lighting technicians, sound engineers, and others.), arguing that as a means of composition, color, light, sound, installation can increase tensions moral conflict characters skills.

Media representations:

- writing the story on behalf of the protagonist or secondary character of a media text: preserving the features of its "moral code" ("identification", "compassion", "co-creation"); 
- rearranged of media text's character in changed ethical situation (with a change of genre, time, place, action media text, its composition: strings, climax, denouement, epilogue, etc.; age, gender, nationality, etc.).

Media audiences:

- writing the monologues on the topic of ethics in the field of media and media texts ("letters" in the editorial offices of newspapers and magazines, on television, in the Ministry of Culture, etc.) with various representatives of the audience age, ethical, social and other data; Here again, we can find support in the V.S. Bibler's "School of dialogue between cultures" [Bibler, 1993, p.27].

Cycle of role game creative tasks that contribute to the ethical analysis of the functioning of media in society and media texts:

Media agencies:

- role game on the topic of ethical relationship of different positions' media agency staff regarding the various ethical problems arising in the course of work on the new numbers of newspapers and magazines, TV / radio programs, films, etc.

Media / media text categories:

- role game on the theme of dialogue of typical characters of comedy, tragedy, melodrama, detective, western, etc., that address ethical issues.

Media languages:

- role game: a dialogue between two artists (directors, cameramen, and others.), arguing that as a means of composition, color, light, sound, installation can increase tensions moral conflict characters skills;

Media representations:

- role game on "press conference with media texts' authors' ("writer", "director", "actors", "producer" and others.); "Journalists" ask the questions concerning the ethical aspects of a media text;

- role game on "international meeting of media critics" is that discuss the ethical aspects of the media in society, analyze the ethical problems of individual media texts, etc.;

- "legal" role game, including the process of "investigation" ethic of media characters.

Media audiences:

- role game on the topic of monologues and dialogues on issues of morality in media texts from audiences with different age, ethical, social and other data;

Graphic-cycle simulation creative tasks that contribute to the ethical analysis skills:

Media agencies:

- creation of draw comics on the topic of ethical relationship of different positions of media agency staff regarding the various ethical problems arising in the course of work on the new numbers of newspapers and magazines, TV / radio programs, films, etc .

Media / media text categories:

- create a series of drawings on the theme of ethical relationships for typical characters of comedy, tragedy, melodrama, detective, western, etc.

Media technologies:

- creation of the images / posters on media topics, which use different technologies (computer, collage, etc.) to ethical conflicts portrayed characters.

Media languages:

- creation of the posters on the theme of the same ethical conflict of media personalities, where the means of composition, color, light, perspective can be strengthened / weakened its strength.

Media representations:

- creation of posters / pictures / cartoons reflecting the ethical issues of media texts;

Media audiences:

- creation of a series of drawings that reflect the reaction of the audience of different age, social, national and religious groups about moral issues in the media sphere.

Cycle of literary and analytical creative tasks, contributing ethical reflection about the functioning of the media in society and media texts:

Media agencies:

- to identify the ethical intentions of the authors and producers of media text.

Media / media text categories: 
- analyze of the ethics of stereotypical characters (in media genres: comedy, romance, detective, western, etc.).

Media technologies:

- analyze of the way in which you can increase tensions ethical conflict focused media text characters using a variety of media technologies.

Media languages:

- analyze of stereotypical image model with the characters or other ethical deviations in terms of plastic, facial expressions, gestures, light-color, sound, solutions.

Media representations:

- analyze of the basic moral qualities of character skills;

- to read/see a number of media texts, which clearly shows the anti-social behavior (crime, violence, false); Note how the characters perform these actions, and to try to classify these characters on the level of moral development.

Media audiences:

- analyze of the main features of the best (worst) installation on the perception of a particular media text from an ethical point of view;

- analyze the best (worst) objective (environment while watching, etc.) and subjective (mood, individual physiological data, etc.) media reception conditions with an emphasis on the ethical aspects;

Arguing about the conditions of media insight, students can apply to their own spectator experience, noting how much disturbed perception of unethical behavior of the audience in the cinema, Internet cafe (loud noises, noise, rowdy antics, etc.), etc.

Game session on writing "on behalf of the character of the story" is on a competitive basis. At first, the audience meets a specific media texts, and then - writes stories on behalf of his principal or secondary characters (taking into account their moral qualities), and then brainstorm results, determined the most successful, close to the original stories.

An important role in shaping the skills of perception and subsequent analysis of media texts play a creative tasks aimed at changing the various components of the works. Students discuss the various options ethical concepts of media texts, making sure at the same time as significantly transformed the perception of the same story if the characters change their moral principles.

Performance indicators creative tasks "on behalf of the character", "character in an altered situation" is the ability of students to identify with a character, its ethics, understand and verbally recreate his psychology, language, to justify his motives and actions (including imaginary missing real product).

Practical mastering typology media insight promote creative tasks, offering the audience to simulate various types of letters in court, written on behalf of the representatives of the audiences of various ages, moral attitudes, etc. An indicator of mastering the material can serve as the ability to identify with an imaginary "recipient" having one or another ethical level.

The next series of classes is problematic group discussions and in reviewing media texts.

Of course, here again the educator can use creative, game, heuristic and problem tasks, significantly increasing the activity and interest of the audience. For example, a heuristic form of the class, in which the audience is invited to a few wrong and right judgment, much easier for the audience analytical tasks. include:

During the implementation of heuristic approaches methodology of training audiences

- true and false interpretation of the logic of ethical position on the material authors of a particular episode of a media text;

- true and incorrect options of ethical concept, unfolding in a particular media text;

- comparative analysis of articles and books of professional media criticism \& journalists, based on the ethical component;

- preparing essays devoted to ethical issues of media culture;

- students' reviews about the specific media texts of different types and genres with an emphasis on ethical issues.

The logic sequence of creative tasks comes from the fact that the critical analysis of media texts begins with an introduction to the works of critics' community professionals (reviews, 
theoretical articles, monographs devoted to ethical issues of media culture and media texts specific), which the audience can judge the different approaches and forms of this type of work.

The audience is looking for answers to the following problem questions: "What is the reviewers' opinion about ethical advantages and disadvantages of the media text?", "How deep reviewers get into an ethical intent of the author?", "Do you agree or not with this or that ethical evaluation of the reviewers? Why? ", etc.

Then - the work on the essay on ethical issues in the media. And only then - brainstorm about ethical subjects media text:

- identification and review content of the scenes of media texts, with maximum brightness embody ethical issues work as a whole;

- analysis of the authors' logic of thinking about media texts: in the development of conflicts, characters, ideas, and ethical concepts, etc .

However, as experience shows, it is necessary, first, to go from simple to more complex media texts. We can to discuss, analyze about the plot, the author's thoughts, the style of media texts. And secondly - discussion about the media text's aim (in the frame of the genre, thematic preferences of the audience).

Classes for the formation of skills of analysis and synthesis of media texts aim to stimulate students' critical thinking, the ability to apply this knowledge in new situations, the psychological, moral work, thinking about moral values, etc.

Questions promote ethical reflection about the functioning of the media in society and media texts [Berger, 2005, p.42, 47; Fedorov, 2004, pp.43-51; Fedorov, 2005; Fedorov, 2006, pp. 175-228]:

Media agencies:

Can the media texts contribute to the promotion of militarism and / or violence?

Can you identify the moral values that are held by the authors of specific media texts?

Media / media text categories:

Can you name the genre, which are the most common characters with aggressive behavior, immoral acts?

Media technologies:

Whether the author is associated ethics media text with technology of its creation?

Media languages:

Can you think of the stereotypical image model with the characters or other ethical deviations?

Media representations:

What ethical issues are displayed in the media text? Are there visible signs of deviant behavior, sexism, conformity, conflict of generations, etc.?

Media audiences:

What is the meaning of ethics in media culture? Does the media texts have the moral evaluation? If so, how to define the criteria of morality?

Do I need to take into account the moral intentions of the authors of media texts in the evaluation of the result of their work?

Is it possible that any media texts can lead to immoral looks at some of the audience?

Are there media texts aimed at the moral manipulation of the audience? If yes, in what media texts is specifically manifested? them?

Can the media texts (eg, advertising of cigarettes, alcohol) harm the audience to perceive

Can the media texts promote racial, class, ethnic, national or religious enmity and hatred?

Can you name the media texts that you do not want to show children aged 7-10 years? Why Are?

What moral values do you personally think it is important to make the basis for the concept of a media text?

Which moral level of audience appeal, the present media text? If you created this media text, and would like to focus on the audience with a higher ethical level, that you would change in the story? 


\section{Conclusions}

This article presented the main directions for Ethical Analysis on media literacy education classes for student audience, including the examples of creative problems and issues associated with this type of the analysis in the context of media literacy education problems, ie based on six key concepts of media literacy education: agency, category, language, technology, audience, representation. The author supposes that the Ethical Analysis of media texts on media literacy education classes can significantly develop media competence of students, including critical thinking.

\section{References:}

1. Baron, M., and Rother, L. (2003). Media Education - an Agent of Change.

2. Berger, A.A. (2005). Seeing is believing. Introduction to visual communication. Moscow: Williams, 288 p.

3. BFI (1990). (British Film Institute). Film Education. Moscow, 124 p.

4. BFI (2003). Department for Education. Look Again! The Teaching Guide to Using Film \& Television with Three-to Eleven-year Olds. London: British Film Institute, $60 \mathrm{p}$.

5. Bibler, V.S. (1993). Dialogue of Cultures and School XXI Century // School of Dialogue of Cultures: Ideas, experiences, challenges. Kemerovo: ALEPH, pp.9-106.

6. Buckingham, D. (2003). Media Education: Literacy, Learning and Contemporary Culture. Cambridge, UK: Polity Press, 219 p.

7. Fedorov, A.V. (2006). Media Education: creative tasks for students and pupils // Innovation in Education. 2006. N 4, pp.175-228.

8. Fedorov, A.V. Specificity of media pedagogical students // Pedagogy. 2004. № 4, pp.43-51.

9. Khilko, N.F. (2001). The role of the audiovisual culture in creative self-realization of the individual. Omsk, $446 \mathrm{p}$.

10. Malobitskaya, Z.S. (1979). Cinema as a means of moral and aesthetic education of high school students. Ph.D. Dis. Alma-Ata.

11. Nechay, O.F. (1989). Fundamentals of cinema. Moscow: Education, pp.167-168.

12. Penzin, S.N. (1987). Movies and aesthetic education: methodological problems. Voronezh: Publishing house of Voronezh. State. University Press, $176 \mathrm{p}$.

13. Potter, W.J. (2014). Media Literacy. L.A.: Sage.

14. Semali, L.M. (2000). Literacy in Multimedia America. New York - London: Falmer Press, $243 \mathrm{p}$.

15. Silverblatt, A. (2001). Media Literacy. Westport, Connecticut - London: Praeger, 449 p.

16. Silverblatt, A. (Ed.). (2014). The Praeger Handbook of Media Literacy (in 2 volumes). Santa Barbara, California and Oxford, England: Praeger.

17. Uritzky, N.C. (1954). Cinema in extracurricular activities. Moscow, 120 p.

\section{УДК 37}

\section{Этический анализ функционирования медиа в обществе и медиатекстов на медиаобразовательных занятиях}

Александр Федоров

Таганрогский институт имени А.П. Чехова, филиал Ростовского государственного университета экономики, Российская Федерация Доктор педагогических наук, профессор

Е-почта: mediashkola@rambler.ru

Аннотация. Этический анализ функционирования медиа в обществе и медиатекстов осуществляется на основе этической теории средств массовой коммуникации. Предполагается, что медиа способны влиять на определенные моральные принципы аудитории. Из этого следует, главная цель медиаобразования, согласно этической теории: 
прививать аудитории моральные качества (соответствующие, например, конкретной религии, уровню цивилизации, демократии и т.д.). Стратегия обучения строится на основе изучения этических аспектов медиа и этического анализа медиатекстов. Эта статья анализирует основные направления этического анализа медиа и медиатекстов в процессе медиаобразования студенческой аудитории, в том числе на примерах творческих заданий, связанных с этим типом анализа в контексте проблем медиаобразования, т.е. на основе шести ключевых понятий медиаграмотности: агентство, категория, язык, технология, аудитория, репрезентация. Автор предполагает, что этический анализ медиатекстов на медиаобразовательных занятиях может значительно развить медиакомпетентность студентов.

Ключевые слова: этический анализ, медиа, медиатексты, медиаобразование, медиаграмотность, медиакомпетентность, студенты. 